\title{
The Internal and Regulatory Environment of Organic Farming in Laguna Province, Philippines
}

\section{Marivic B. Abinsay}

\begin{abstract}
This study was conducted to assess the internal environment and regulatory environment of organic farming in Laguna province. A total of 86 organic farmers in selected municipalities in Laguna participated in the study. The research design employed was the descriptive method. Weighted means were used in the data analysis. The findings indicated that the internal environment in terms of operational sustainability and market sustainability is perceived as sustainable, while the regulatory environment in terms of standardization and certification is also perceived as sustainable. Results suggested that the perceived operational sustainability and market sustainability of organic farming imply a bright perspective in the province. Modification/amendments of the certification standards and regulations are essential mandates to increase adoption and to reach local and foreign market and must be attuned to the needs of small farmers. Improvement on internal systems in operational sustainability and local market sustainability is also recommended.
\end{abstract}

Keywords:

sustainable, organic farming, internal environment, regulatory environment

Suggested Citation: Abinsay, M. B. (2021). The Internal and Regulatory Environment of Organic Farming in Laguna Province, Philippines. International Journal of Academe and Industry Research, Volume 2, Issue 1, pp. 21- 44.

About the author:

Administrative Officer, Department of Education - San Pablo City, Laguna, Philippines. 


\section{Introduction}

Agriculture today places great strains on biodiversity, soils, water and the atmosphere, and these strains will be exacerbated if current trends in population growth, meat and energy consumption, and food waste continue. Likewise, awareness of the negative impacts of conventional agriculture to the environment, health, socio-economic and cultural well-being of people is gaining momentum with consumers around the world. Thus, organic agricultural systems deliver greater ecosystem services and social benefits (Reganold\&Wachter, 2015). In the quest for higher yield, low input cost, and sustainability, the Philippines is now delved into natural farming system. As the trend towards healthier lifestyle continues to grow, the interest in organic farming in the country is also expeditiously gaining ground.

Social, organizational, and institutional factors are important elements in the growth of organic agriculture. Different social arrangements and a supportive environment such as training opportunities, resource access, and organizational support, have accompanied the growth of organic farming. The private sector and civil society groups have placed organic agriculture in the policy agenda, but the dynamics in the policy and administrative contexts has influenced as well the sustainability of policy initiatives (Salazar, 2014). A significant barrier for wide application and future development of organic farming is the existing diversity of national and international policy instruments in this sector. Special attention is paid to up-to-date research techniques that could help solve a number of the problems typically faced in plant organic farming. It is argued that organic farming is still not productive enough to be considered fully sustainable. This underlines the necessity of strong support for more effective implementation of scientific research innovations and improvement of the networking between all stakeholders - organic producers, scientists and corresponding policy makers at the national and international level (Tsvetkov et al, 2018).

Organic agriculture (OA) policy directions in the Philippines encourage more farmers to become organic growers to sustain their livelihood, health, and environment, and prepare them for the global challenges. Since organic agriculture is a promising technology to support environmental sustainability and rural development, the Philippines created into law the Organic Agriculture Act of 2010, Republic Act 10068, which provides for the 
development of the country's organic agriculture (Rola, et al, 2016). It provides for policy and governance structure and covers the operational policies of production and postproduction support, market support, certification, labelling, LGU support, research and development, extension, and capacity building.

In spite of a growing interest in organic agriculture, there has been relatively little research on why farmers might choose to adopt organic methods, particularly in the developing world (Olabisi, et al., 2015). Despite the effort of the Philippine government to promote organic agriculture, its adoption rate is still low (Pantoja, Badayos \& Rola, 2016). In agreement, Shimoguchi and Mojica (2016) described shifting to organic farming and maintaining an organic farm are not easy tasks due to issues such as lack of knowledge on suitable production technologies, unstable supply, lack of markets, intensive labour inputs and difficulty in controlling weeds, pests and diseases to name a few. Along this venture, the province of Laguna supports the policy implementation on organic agriculture. Though there has been organic farming projects by universities and government agencies, organic agriculture in the province has apparently been slow in its uptake and majority of the farmers are still into conventional practices. In 2017, the documented practitioners of OA were 30 farmers only with an average area of 1 to 2 hectares of production area. Some organic farms were able to sustain operations such as Costales Natures Farm which remained in the business and continue to grow given the changing business environment (Shimoguchi \& Mojica, 2016).

Given the current status and the challenges faced by the OA in the country, this study assesses fundamental factors contributing to its dawdling development. It particularly focus on the internal and regulatory environment to determine its probable contribution to the operational sustainability of the OA in the country. The internal environment is assessed through organizational set-up, institutional support system, financial viability and technical soundness. Meanwhile, the regulatory environment is assessed through standardization, certification and regulatory policy.

\section{Literature review}

\subsection{The Internal Environment of the Organic Farming}

\subsubsection{Organization and Management}


Business operational sustainability is a method of evaluating whether a business can maintain existing practices without placing future resources at risk. Sustainability can refer to any one of a variety of areas, though it is often linked to ecological resources. Operational sustainability is also focused on social or economic resources. Operational sustainability from the ecological standpoint refers to a company's ability to use natural resources at its current pace without depleting the resources it relies upon. This can be a company perspective or an industry-wide perspective (Leonard, 2015). Inspired by this end. strengthening agricultural organizations and promoting organic agriculture have received increasing attention in the Philippines especially after the declaration of Republic Act 10068. However, organizations alone cannot achieve these goals on its own (De Guzman, et al. 2017). There is a need for a collective understanding of the goals of the programs among different organizations for the successful promotion of organic agriculture. There is a need to establish linkages and networks among organizations engaging in organic agriculture because this will facilitate coordination of organic agricultural programs (National Organic Agriculture Board, 2011). This indicates that organizations have to unite with internal and external expectations while securing legitimacy and efficiency within a constantly changing environment (Rosenow-Williams, 2014). Organizations also exist with external environment necessitating them to have exchanges with other organizations. As pointed out by de Guzman, et. al (2017), there are also relationships formed because there is a formal agreement or legal mandate. Studies conducted in the Philippines found out that organizations are active in promoting organic agriculture. There are also umbrella organizations composed of network of people's organizations (POs), non-government organizations (NGOs) and scientists which led the sustainable use and management of resources, indigenous practices and independence from using farm inputs. Through the initiatives of farmers' organizations and NGOs, many international donors supported organic agricultural projects (Carating, et. al 2010). With the same view Nelson, et.al (2015), justify demonstration farms were also established by organizations to improve agricultural production through farm-based learning. This active participation of organizations is vital in the successful implementation of organic agriculture program. In addition, Kanten, Kanten, \& Gurlek (2015) disclose that organizational structures can have a major impact on organizational outputs and the attitudes of members. 


\subsubsection{Institutional Support System}

It is important to continuously assist farmers and communities in developing their resilience and sustainability in light of the on-going socio-economic and climatic changes. This is linked with institutional aspects and in this light the most crucial sustainability attribute of organic agriculture may be its basis in farmer driven entrepreneurship and organizations (Halberg, 2012). Yasseen, et al. (2015) stated that capacity building and training programs have important role to boost up house hold income of farming community. The government should launch massive programs for capacity building and training of rural communities in agriculture and livestock, so that the poor farmers become capable and skilled to raise their farm production and improve their livelihood.

Nikolić, Vuković, and Grujić (2017) analyse the situation in the sector of organic agriculture, as well as system of support that this production provides in the European Union and Serbia. It was found out that intensive growth of organic farming in the EU provides a stable support both in terms of rate and financial resources. On this basis, it was concluded that a stable government support is crucial for boosting growth and improving the sector of organic agriculture. Furthermore, according to Oluoch-Kosura (2010), institutional support systems are needed to help integrate smallholders into national economic systems. Smallholder farming has been the institutional structure underpinning some of the most effective contributions of agriculture to economic development. In addition, institutional reforms will play out in five functional areas critical to agricultural growth: contractual arrangements, functioning financial markets, agricultural insurance, public-private partnerships and vibrant producer organizations.

In the Philippines, Salazar (2005) narrates that low-income smallholders tend to succeed when given adequate training and assured of inputs and markets. Small farmers' cooperatives and non-governmental networks and organizations are important sources of support. In turn, relatively larger, corporate farms benefit from having access to adequate resources, technological know-how, and an effective marketing system. Furthermore, in the study conducted by Sarmiento (2006), some issues were identified to have constrained the adoption of organic agriculture in the Philippines. Partap (2010) underpins that a critical challenge for Asian organic agriculture is how to sustain its expansion. 


\subsubsection{Financial Viability}

Organic farmers must face different risks than conventional farmers due to the special features of management of their productive system, and due to the specific characteristics of their cultivations (Medina and Iglesias, 2008). To survive in the changing business environment and to be financially healthy are essential objectives to be met by all enterprises in today's globalized and highly competitive world. The scientific sphere pays substantial attention to financial health issues. The position of organic farm enterprises among business entities is very distinct and special (Brožová, 2011).

The study of Berban (2008) noted that if organics is to be viable for low-resource people, it may be necessary to promote both resources and techniques in organics initiatives. The challenge facing policymakers is to develop government policies that support conventional farmers converting to organic and other more sustainable systems, especially during the transition period, often the first three years. Furthermore, results of the study of Torres, et. al (2016); Ohlan (2016) revealed that profitability of organic farming is higher than that of conventional farming and of interest to other agricultural areas of compromised profitability. A shift towards organic production can represent a viable alternative for the economic and social sustainability. Therefore, organic farming seems to be a viable option to improve food security of smallholding farms by increasing income/decreasing input cost; producing more for home consumption, and adopting ecologically sustainable practices with locally available resources but, improvement is needed further for all dimensions of food security (Paneerselvam and Hermansem, 2011).

Palšová (2014) confirms that the main motivation behind the farmers 'decision to change the conventional to organic production is still a financial incentive to compensate the loss of the income from reduced production and additional costs related to the implementation of organic farming. While the motivating factor would definitely be the farmers' support from the part of the state in the forms of enhancement of the sales of organic products, improved counselling system and promotion.

\subsubsection{Technical soundness}

Nowadays, technology is one of the most important drivers for change and not only important for the implementation of change (Dälken, 2014). The farming practice which 
involves the use of eco-friendly methods to grow crops and the exclusion of synthetic products, such as chemical fertilizers, insecticides and pesticides are described as organic farming. According to Lassen (2015), consumers regard organic technologies as the opposite of conventional farming. Organic consumers base their assessment of alternative strategies and technologies primarily on concerns about environmental risks (pollution) and consequences for human health. Likewise, Brown, del Rosario and Aganon (2015) strongly emphasize that it is also imperative to ensure access to resources and to address whatever technical disadvantages associated with organic farming.

Organic farming is a technical process which involves some degree of complexity. It is not merely the use of organic fertilizer but also involves a whole new set of practices to control pests and ensure the organic integrity of the farm. Lack of knowledge or technical skills can serve as a barrier to adoption of this practice. Add to this the fact that the beneficial effects may take time and, at least during the conversion period, profitability may even be lower. No wonder then that there are still few adopters of this practice despite the long years of promotion of this technology.

\subsection{The Regulatory Environment of the Organic Farming}

\subsubsection{Standardization of organic agriculture and its products}

Standards play an integral part in ensuring food safety and quality. They define production methods and regulate minimum requirements for organic production as well as facilitate easy implementation of the necessary regulations (Layese, 2008). The development of organic farming and its standards needs to respect the traditional ecosystem and technological knowledge of farmers. Regulations and all activities to monitor them must respect cultural diversity and must not try to bring the various farmer cultures worldwide into line. Organic farming is a promising agricultural method with positive effects on the human ecological and social environment. Governments have taken over a major role in defining organic farming by creating legal standards. Many countries all over the world have established a certification and accreditation system in order to protect the justified expectations of consumers with regard to processing and controlling the product quality of organic goods and to protecting producers from fraudulent trade practices. As they are relevant to international trade, these standards do not only influence the organic farming 
movement on the national level but also have a converse impact across national borders (Vogl, Kilcher, and Schmidt, 2005).

In this context, standardization seems to be a cost-driven strategy for marketers, as it leads to leveraging the same template/product/service configuration globally, creating economies of scale and cost savings. When implementing a standardization strategy, homogenized consumer needs were assumed by the company. Investments in international market research were related to modifying the marketing mix of the market. The marketing mix includes company efforts related to four basic P's of marketing: Product, Price, Place (distribution), and Promotion (Solis, 2012). As mentioned by Maghirang, et al (2011), the challenge really is to ensure that food production and processing guidelines, food safety standards and food regulatory measures are followed to assure food safety. Consumers should be protected against false, misleading health claims or labels that would create erroneous impression that processed food products superiority to others just because of the agricultural method or system employed.

The Philippine Organic Agriculture Act was put into law in 2010 and is currently being implemented by the Department of Agriculture and other concerned national government agencies and local government units. Because of this law, a budget is allocated for the promotion of organic agriculture throughout the country. Thus, training and seminars and other information and education campaign activities are available and accessible to the smallholder farmers. The local government units have also facilitated the organization of farmers engaged in organic farming. As such, the smallholder farmers could enhance their social and financial capitals that would help sustain their farming system (Landicho et al, 2014).

\subsubsection{Certification of organic agriculture practices and products}

Certification is the procedure by which official certification bodies or recognized official certification bodies provide a written or equivalent assurance that the foods or food control systems conform to requirements. Certification is a strong market tool that serves to build trust in organic agriculture and products. One organic standard that is applied by all organic producers, certified or not, helps to build energy and joint activities in the sector. Stakeholder involvement is critical in standard development, especially in the early stage 
(IFOAM, 2008). There are group certification schemes where the group of farmers shares the certificate and certification fee among themselves (Maghirang, et al, 2011).

Corollary, certification program is done by independent body and it is the production system, the process, or the method rather than the product that is being certified as organic. Certification activities include standards setting, inspection, and certification. The National Standards Specification for Organic Agriculture was initially prepared by the Organic Certification Centre of the Philippines (OCCP) and was adopted in 2003 by the Department of Agriculture - Bureau of Agriculture and Fisheries Product Standards (BAFPS) after series of technical reviews and public consultations. The standards covered the conversion to organic agriculture, crop production, livestock, processing, special products, labelling, and consumer information. The document is released as PNS/BAFPS 07:2003 ICS 65.020 and available in the PCARRD website. The Department of Agriculture has accredited OCCP as the sole certifying agency for organically grown agriculture products. Although organic agriculture in the Philippines is still in its emergent or incipient phase, the philosophy of organic agriculture is fast gaining ground in the country. Organic agricultural production is limited though steadily growing, reportedly between 10-20 percent annually (FAS/USDA, 2000), but reliable statistical data are hardly available. In many developing countries like the Philippines, where certification-oriented organic farming is only recently emerging, the extent to which these benefits have been achieved and the conditions under which these are attained remain unclear (Salazar, 2005). The organic market in the country has been described as a "niche market". The important role of DTI through the Business Development Programme for organic certification for export cannot be underestimated. DTI worked very hard to partner with foreign certifying bodies to enable the country to generate additional revenues through export of organic products (Carating, et.al, 2010).

\subsubsection{Regulatory Policy Support for Organic Agriculture}

The government based on some of its policy instruments is also committed to promoting organic farming. However, the instruments are inadequate and not well integrated. Inadequate research, extension services and manpower especially on production and marketing information and input supply have hindered promotion of organic agriculture. Organic product legislation, standardization, certification and infrastructure in such 
development are also major issues of policy concerns (Pokhrel and Pant 2009). In this light, Maghirang, et al (2011), denote the following national policies and regulations which influence the development of organic agriculture throughout the Philippines such as the Philippine Agenda 21 (PA 21), officially known as the National Agenda for Sustainable Development and the Agriculture and Fisheries Modernization Act (AFMA), which stipulates the government's policy to ensure the development of the agriculture and fisheries sectors.

The Department of Agriculture through the Bureau of Agriculture and Fisheries Product Standards (BAFPS) approved the establishment of the Philippine National Standards for Organic Agriculture (PNSOA). These Standards for organic agriculture have been prepared for the purpose of providing a uniform approach to the requirements, which is the basis of the following: conversion to organic agriculture, crop production, livestock, processing, special products, labelling and consumer information. In 2004, the Philippine National Organic Board was created to support among others, the implementation of the Philippine National Organic Standards and Certification system; and the establishment of a Five-year Organic Industry Development Program for adoption by the respective units of DA in partnership with the private sector. Department of Agriculture Administrative Order No. 25 Series of 2005 - Guidelines on the certification of Good Agricultural Practices (GAP) for fruits and Vegetable Farming (FV). This establishes the rules applied by the Department of Agriculture (DA) for granting, maintaining and withdrawing Good Agricultural Practices (GAP) Certificate to individual growers or farms in the fresh fruit and vegetable sector or to their Produce Marketing Organizations (PMOs) that market and or trade the produce.

The certification of agricultural farms is aimed to increase the market access of horticultural products both in the local and foreign markets, to empower farmers to respond to the demands of consumers that specific criteria to achieve food safety and quality be met, to facilitate farmer adoption of sustainable agricultural practices, to uplift GAP-FV farmers profile as member of the nationally recognized list of vegetable farmers who are setting the benchmark for the production of safe and quality fruits and vegetables, and to enable consumers exercise the option of buying quality fruits and vegetable from traceable and certified sources. 
Providing the bright perspective of OA, Aquino, Deriquito, and Festejo (2013), herald that the Philippines is looking at a competitive organic agriculture industry with the government's deeper commitment to organic farming support especially in terms of organic certification and research, development and extension. With about $80 \%$ of the poor populace in rural areas dependent on subsistence agriculture, the proper implementation of the Organic Agriculture Act could help answer affordability issues in food production as well as issues of food security, environmental concerns and climate mitigation.

\section{Methodology}

The study used descriptive research method through the survey strategy. It particularly assessed the internal and regulatory environment of the OA in Laguna Province using a self-made questionnaire as the main data gathering tool.

The researcher, as an agriculturist herself, drafted the guide questions relevant to these factors. The questionnaire is a four-point Likert scale type. It has undergone two processes of validation: (1) content and (2) concurrent validity. On content validation, it was validated by three (3) experts in the field of agriculture. The concurrent validity made use of Cronbach Alpha. The concurrent validity based on Cronbach Alpha indicated 0.970, a greater internal consistency in the questionnaire.

The researcher personally facilitated the data gathering during the month of May 2017. Due to the limited official data from the provincial Department of Agriculture, the researcher started identifying popular and registered organic farms in the province. An official letter request and guide questionnaires were sent and the schedule was set. The researcher visited the farm site to conduct the data gathering as well as farm tour for better experience of the actual farm practices.

To compensate for the unavailability of the list of registered organic farms, the researcher opted to use snow ball approach in the selection of the participants. Each farm owner suggested another organic farmer within their area. At the end of the process, a total of 86 organic farmers in selected municipalities in Laguna were identified and participated in the study. 
Weighted means were used for data analysis of the internal and regulatory factors of organic farming in Laguna Province.

\section{Findings and Discussion}

\subsection{Internal Environment of Organic Farming}

Table 1

Assessment of the organizational set up

\begin{tabular}{lllll}
\hline No. & \multicolumn{1}{c}{ Indicators } & WM & SD & VI \\
\hline 1 & $\begin{array}{l}\text { Sole proprietorship ownership } \\
\text { leads to ease of operation through } \\
\text { empowered decision making. }\end{array}$ & 3.07 & 0.02 & Agree \\
$2 \quad \begin{array}{l}\text { Operating as family business } \\
\text { ensures availability of key leaders } \\
\text { to carry on with all the } \\
\text { management functions. }\end{array}$ & 3.09 & 0.01 & Agree \\
$\begin{array}{l}\text { Human resource management } \\
\text { assures availability of manpower } \\
\text { whenever the need arises. }\end{array}$ & 3.14 & 0.03 & Agree \\
\hline & General Weighted Mean & $\mathbf{3 . 1 0}$ & & \\
\hline
\end{tabular}

Legend: 3.25-4.00 Strongly Agree; 2.50-3.24 Agree; 1.75-2.49 Disagree; 1.00-1.74 Strongly Disagree

Table 1 presents the assessment of the organizational set up as a contributory factor to operational sustainability. A general weighted mean of 3.10 implied that the current organizational setup of the organic farming was perceived to be sustainable. Of the three indicators, the highest scorer was "Human resource management assures availability of manpower whenever the need arises." with a weighted mean of 3.14, "Agree". The lowest scorer was "Sole proprietorship ownership leads to ease of operation through empowered decision making." with a weighted mean of 3.07, "Agree".

Along the findings, the form of organization is sole proprietorship for all the participants interviewed. They either have regular or part time employees when need arises. In addition, Tadeo, et.al (2012) emphasize that organic farming enhances the capacities of farmers to be self-sufficient (through the production of organic fertilizers and pesticides) and 
by reducing the risks of indebtedness, organic farming restores agriculture as a viable livelihood for rural communities. According to Carating \& Tejada (2012), one type of existing organic agriculture is the small scale subsistence organic farms.

Table 2

Assessment of the institutional support system

\begin{tabular}{lllll}
\hline No. & \multicolumn{1}{c}{ Indicators } & WM & VI \\
\hline $\mathbf{1}$ & $\begin{array}{l}\text { Trainings, workshops and seminars are } \\
\text { conducted by government agencies to } \\
\text { keep organic farmers abreast on trends } \\
\text { and innovations on organic farming. }\end{array}$ & 3.23 & 0.16 & Agree \\
$\mathbf{2} \quad \begin{array}{l}\text { Extension services and technical } \\
\text { assistance are provided by the } \\
\text { government agencies to ensure the } \\
\text { sustained adoption on organic farming. }\end{array}$ & 3.19 & 0.13 & Agree \\
$\mathbf{3} \quad \begin{array}{l}\text { Organic farmers have access to } \\
\text { agricultural extension services to } \\
\text { enhance their organic farming practices. }\end{array}$ & 3.17 & Agree \\
$\begin{array}{l}\text { Marketing support and linkages to } \\
\text { sustainable organic farming practices } \\
\text { are provided by government agencies to } \\
\text { farmers. }\end{array}$ & 2.92 & 0.12 & Agree \\
$\begin{array}{l}\text { The government provides subsidies to } \\
\text { organic farmers to ensure operational } \\
\text { sustainability. }\end{array}$ & 2.60 & 0.06 & Agree \\
$\begin{array}{l}\text { Organic crop insurance is made } \\
\text { available and affordable to organic } \\
\text { farmers. }\end{array}$ & Agree \\
\hline General Weighted Mean & Agree \\
\hline Legend: $3.25-4.00$ Strongly Agree; 2.50-3.24 Agree; 1.75-2.49 Disagree; $1.00-1.74$ Strongly Disagree
\end{tabular}

Table 2 makes clear how the institutional support system is perceived by the participants. A general weighted mean of 3.00, "Agree" suggested that participants perceive that institutional support system is sustainable. The highest indicator was the item "Trainings, workshops and seminars are conducted by government agencies to keep organic farmers abreast on trends and innovations on organic farming" with a weighted mean of 3.23 , "Agree". The lowest indicator was the item "The government provides subsidies to organic farmers to ensure operational sustainability" with a weighted mean of 2.60, "Agree". 
Intensive support and technical assistance, and comprehensive programs are needed for organic farming to be a mainstream practice in the province. In depth and breadth of the findings, according to Tim, et al (2011), extension activities for enhancing sustainable agriculture through conducting workshops and model organic farm demonstrations have favourable effect on local farmers. It was also concluded that local farmers were confident in the various extension activities and that it is the most important key to increase local acceptability. Piadozo, et al. (2014) recommend that stakeholders should be provided with the needed information on certification, health and environment, adaptability, cultural practices and insecticides/pesticides used in organic farming.

Table 3

Assessment of the financial viability

\begin{tabular}{lllll}
\hline No. & \multicolumn{1}{c}{ Indicators } & WM & SD & VI \\
\hline 1 & $\begin{array}{l}\text { Organic farming is financially } \\
\text { viable because of the income } \\
\text { generated from exports. }\end{array}$ & 2.56 & 0.16 & Agree \\
2 & $\begin{array}{l}\text { Operation of organic farming is } \\
\text { cheaper to maintain. }\end{array}$ & 2.90 & 0.08 & Agree \\
3 & $\begin{array}{l}\text { There is high premium for organic } \\
\text { food products. }\end{array}$ & 2.63 & 0.11 & Agree \\
$4 \quad \begin{array}{l}\text { Organic farming is a low-risk } \\
\text { farming strategy that reduces costs } \\
\text { of external inputs for higher } \\
\text { income generation. }\end{array}$ & 2.90 & Agree \\
$\begin{array}{l}\text { Organic Farming is financially } \\
\text { and economically viable higher } \\
\text { market demand. }\end{array}$ & 2.87 & 0.06 & Agree \\
\hline $\begin{array}{l}\text { Organic farm operations require } \\
\text { less financial capacity of farmer- } \\
\text { owners. }\end{array}$ & 2.86 & 0.06 & Agree \\
\hline$\quad$ General Weighted Mean & $\mathbf{2 . 7 8}$ & & \\
\hline
\end{tabular}

Table 3 exposes the perceived operational sustainability in terms of financial viability. A general weighted mean of 2.78, "Agree hinted that organic farming was perceived to be sustainable. Of the six indicators, the highest rate was "Operation of organic 
farming is cheaper to maintain" and "Organic farming is a low-risk farming strategy that reduces costs of external inputs for higher income generation" with a weighted mean of 2.90, "Agree. The lowest rate was the item "Organic farming is financially viable because of the income generated from exports" with a weighted mean of 2.56, "Agree.

Findings were sided by the results of the study of Brown, Del Rosario and Aganon (2015) which concluded that despite lower productivity, organic vegetable farming is more profitable than conventional production. In Nueva Ecija, Philippines, yield per hectare of organically grown eggplant is 24 percent lower than in conventional farms. However, net income per hectare is considerably higher in organic than conventional farms owing primarily to the high premium price received for organically grown products. Similar findings were derived for organically grown okra and lettuce in Nueva Ecija. The single most important factor for the higher profitability of organic vegetable farming is the premium price attached to organically grown products. Such higher profitability is assured as long as the price difference between organic and conventional products is more than enough to offset the yield difference.

Based from this result, Geisen (1999) in his study at Guimaras, Philippines, exposes that as the production system is very labour-intensive and produces high returns on comparatively small farm lots, the system is basically ideal for a situation in which capital is scarce, land holdings are small and labour is sufficiently available. Alongside, Crowder and Reganold (2015) analysed the financial performance of organic and conventional agriculture from 40 years of studies covering 55 crops grown on five continents and found that, in spite of lower yields, organic agriculture was significantly more profitable than conventional agriculture and has room to expand globally. Moreover, with its environmental benefits, organic agriculture can contribute a larger share in sustainably feeding the world.

Table 4 shows the assessment of the technical soundness. A general weighted mean of 3.03, "Agree" specified that organic farming was perceived to be sustainable. The highest scorer was "Organic farmers utilize available package of technology as support to efficiency of farm operations" with a weighted mean of 3.13, "Agree". This was followed by the indicator "Research and development activities in organic farming help address the problems and issues of organic farmers." with a weighted mean of 2.93, "Agree". 
Table 4

Assessment of the technical soundness

\begin{tabular}{lllll}
\hline No. & \multicolumn{1}{c}{ Indicators } & WM & SD & VI \\
\hline $1 \quad$ & $\begin{array}{l}\text { Organic farmers utilize available } \\
\text { package of technology as support to } \\
\text { efficiency of farm operations. }\end{array}$ & 3.13 & 0.07 & Agree \\
\hline $\begin{array}{l}\text { Research and development activities in } \\
\text { organic farming help address the } \\
\text { problems and issues of organic farmers. }\end{array}$ & 2.93 & 0.07 & Agree \\
\hline & General Weighted Mean & $\mathbf{3 . 0 3}$ & Agree
\end{tabular}

Legend: 3.25-4.00 Strongly Agree; 2.50-3.24 Agree; 1.75-2.49 Disagree; 1.00-1.74 Strongly Disagree

The findings are well defined by Crowder, and Reganold (2015) in assessing the "willingness to convert" of conventional farmers shows some potential for converting to organic practices. Lack of knowledge and skills needed to manage an organic farm and lack of market opportunities for organic products are the most important reasons for not using organic farming practices. In contrast to some research, the findings showed that nonprofitability of organic farming is not a significant reason for not adopting organic farming practices. Herath, and Wijekoon (2013) imparted that organic growers practice organic farming mainly because of the marketing assistance and the inputs such as organic fertilizer and technical know-how provided to the farmers. Participatory extension programs and better extension approaches such as farmer field schools could be recommended to change growers' attitude, knowledge and skills towards organic farming. Further involvement of a third party like the government, an NGO or a private company to assist organic growers will also increase the adoptability of organic farming. According to Huang (2010), technology improvement will be the key for future development of organic farming. Appropriate production technology, particularly the control of insect pests and pathogenic diseases, is highly important to organic farming especially in areas with humid, high temperature weather conditions, such as that in ROC. If insect pests and diseases can be controlled without using any agrochemicals, then size of organic farms will expand dramatically. 


\subsection{The Regulatory Environment of Organic Farming}

Table 5

Assessment of the Standardization and Certification, and Regulatory Policy

\begin{tabular}{lllll}
\hline No. & \multicolumn{1}{c}{ Indicators } & WM & SD \\
\hline 1 & $\begin{array}{l}\text { Organic farms meet the required } \\
\text { certification standard that enables the } \\
\text { efficacy of the operations and quality } \\
\text { assurance on products and services. }\end{array}$ & 2.83 & 0.06 & Agree \\
$2 \quad \begin{array}{l}\text { Local organic certifications are } \\
\text { subsidized and localized in order to } \\
\text { assist the small-scale organic } \\
\text { farmers. }\end{array}$ & 2.87 & 0.09 & Agree \\
3 & $\begin{array}{l}\text { The certification process is aligned } \\
\text { with the interest of the small farmers. }\end{array}$ & 2.63 & 0.08 & Agree \\
$4 \quad \begin{array}{l}\text { Local government policies assure } \\
\text { assistance to organic farmers and } \\
\text { facilitate adoption of organic } \\
\text { farming. }\end{array}$ & 2.60 & 0.10 & Agree \\
$\begin{array}{l}\text { Organic Agriculture Act ensures the } \\
\text { adoption of organic farming practices } \\
\text { at the local level. }\end{array}$ & 2.79 & 0.04 & \\
\hline
\end{tabular}

General Weighted Mean $\quad \mathbf{2 . 7 4}$ Agree

Legend: 3.25-4.00 Strongly Agree; 2.50-3.24 Agree; 1.75-2.49 Disagree; 1.00-1.74 Strongly Disagree

Table 5 displays the perceived sustainability of organic farming in terms of standardization, certification, and regulatory policy. A general weighted mean of 2.74, "Agree" indicated that organic farming certification, standardization, and regulatory policy is perceived to be sustainable. Of the five indicators, the top rate was "Local organic certifications are subsidized and localized in order to assist the small-scale organic farmers" with a weighted mean of 2.87, "Agree". The lowest indicator was "Local government policies assure assistance to organic farmers and facilitate adoption of organic farming" with a weighted mean of 2.60, "Agree".

Growers in Nueva Ecija, Philippines are able to enjoy the premium attached to organic products even though their farms are not certified. Except for the associated cost however, their view of third party certification is positive. They believe such certification will enable their products to penetrate a wider market. Since the cost of certification is the major constraint faced by farmers, it would be useful for the government to subsidize such 
cost at least partially if not completely. Group certification must also be done to minimize cost. Furthermore, environmental protection and ensuring consumer food safety are enough justification for the government to subsidize organic farming. So far, the whole organic farm business in the country has been initiated and supported largely by civil society, especially those with strong advocacy for the environment. It is high time for the government to take the helm and ensure the growth of organic agriculture in the country (Brown, del Rosario and Aganon 2015).

Findings were supported by the explanation of Khaledi, et al, (2007) that increased domestic and international demand for organic products, along with environmental and safety issues, have stimulated policymakers and governments in some parts of the world to provide incentives for converting from conventional to organic farming. Seconded by Carreón, et al (2011), that the goal of developing sustainable agriculture is the responsibility of all participants in the system, including farmers, workers, policy makers, researchers, retailers and consumers. Each group has its own part to play and its own unique contribution to strengthen the sustainable agriculture community. Considering the concepts that farmers include in each model of farming practice will help the transition from a conventional to a sustainable agriculture. According to Njeru (2015) organic farmers realized positive benefits in carrying out organic farming which are manifested in the increased production and improved environmental conservation. However, crucial aspects of marketing and certification were challenges that farmers faced in carrying out organic farming. Aggressive marketing and awareness creation can greatly improve the organic farming sector. Consumers play a key role in the future development and growth of organic farming. Some of these challenges can be addressed by an elaborate policy on organic farming. Therefore, if all stakeholders worked in harmony towards the growth and support of organic farming, both the farmers and the environment will greatly benefit from this vital sector. Organic farming holds a great potential which can be exploited as a path towards sustainable development if the challenges identified can be addressed and intensify on the benefits accruing from organic farming.

Regarding the results, Salazar (2005) stresses that the development of markets on the one hand and the certification standards on the other, both illustrate the role of civil society groups, environmental activists among them. As Willer and Lernoud (2015) point out, while 
the Philippines has legislatively put in place its national organic food standards, the organic food certification system has yet to be fully implemented. Moreover, Rule 24.10 of the implementing rules and regulations states that 'group certification for contiguous farms adopting the same farming system shall be encouraged'. Indeed, an area-based organic food certification system is vital for promoting community-based organic farming.

In agreement with the result, Suh (2015) flaunts that the Philippines need to formulate an area-based organic food certification systems and a government-farmers partnership should be forged to facilitate farmers' access to domestic and international organic food markets. Likewise, Khaledi, et al, (2007) said that the certification bodies are important institutions that can improve organic farming by providing efficient and timely certification, providing objective certification, providing affordable certification, helping farmers and buyers connect with each other, providing production/agronomic information, performing research in agronomy and marketing, distributing research knowledge to members, and participating in the creation of a mandatory national standard.

In sum, under the Organic Agriculture Act of 2010 by which the government will subsidize the expenses for certification following a set of guidelines and ensures that the farmers would try to meet the standards after being given a two-year period to scale up and meet the requirements for certification (Maghirang, et al, 2011). The agricultural development programme of the Government of the Philippines still favours heavily the development of intensive cropping systems using synthetic inputs. The rationale behind this is the need to ensure food security for the growing population. On rice for instance, much support is currently given on the promotion of high yielding hybrids which require heavy use of chemical inputs. There are some programmes designed to minimize use of chemicals; however, much is still wanting in terms of government support if the country is to shift successfully towards more environmentally friendly practices. The government should provide a programme of support, which will enable farmers to remain afloat during the critical conversion from conventional to organic.

The Philippines is now looking at a competitive organic agriculture industry with the government's deeper commitment to organic farming support especially in terms of organic certification and research, development and extension. With about $80 \%$ of the poor populace 
in rural areas dependent on subsistence agriculture, the proper implementation of the Organic Agriculture Act could help answer affordability issues in food production as well as issues of food security, environmental concerns and climate mitigation. (Aquino, Deriquito, and Festejo, 2013).

\section{Conclusion}

Based on the findings, the perceived operational sustainability of organic farming implies a bright perspective in the field of agriculture. Moreover, amendments of the certification standards and regulations are essential mandates to increase adoption and to reach local and foreign market. This modification is called for the small farmers to experience the advantages of engaging in organic farming in local setting.

The country must strongly implement the Organic Agriculture Act. It should focus alignment of Philippine National Standards with the global standards. However, it should concentrate first on localization by improving local plans, passing ordinances that will support the OA practitioners, strengthening the organic producers and consumer awareness, and assistance or free certification.

The following recommendations are forwarded for the future of organic farming in the Province of Laguna: intensification of organic farming practices and strengthening of the methods and procedures employed in organic farming in the province of Laguna; improvement on internal systems in operational sustainability and local market sustainability; and review and amendments of organic agriculture act specifically on the certification to be attuned to the needs of small farmers. Further studies can be carried on the local implementation of the Organic Agriculture Act and the utilization of the organic agriculture local budget.

\section{References}

Aquino, A.P., J. A. P. Deriquito, and M.A. Festejo. (2013). Organic Agriculture Act towards a Greener Philippines.

Brown, Ernesto O., Beatriz del Rosario Clarita P. Aganon. (2015). The role of Market Intermediaries in Promoting Organic Rice Production: Nueva Ecija. FAO. www.fao.org/publications. 
Brožová, I. (2011). Financial Health of Agricultural Enterprises in the Organic Farming Sector. Acta Universitatis Agriculturae Et Silviculturae Mendelianae Brunensis. Volume LIX, Number 7, 2011. Pp. 91-96

Carating, R.B., M. Fernando, Y. Abrina, and S.Q. Tejada. (2010). State of Organic Agriculture in the Philippines: The Philippine Country Report. Paper presented during the Workshop on ANSOFT of AFACI PAN-ASIAN Project 29-30 November 2010, Suwon, and the Republic of Korea.

Carating, R.B., S.Q. Tejada. (2012). Sustainable Organic Farming in the Philippines: History and Success Stories. Bureau of Soils and Water Management, Elliptical Road, Diliman, Philippines.

Carreón, J.R., R.J. Jorna, N.Faber, R.van Haren. (2011). A Knowledge Approach to Sustainable Agriculture. Global Food Insecurity: Rethinking Agricultural and Rural Development Paradigm and Policy, DOI 10.1007/978-94-007-0890-7_2, Springer Science+Business Media B.V. 2011. Pp.11-20. http://www.springer.com/978-94-0070889-1.

Crowder, D.W., J.P. Reganold. (2015). Financial competitiveness of organic agriculture on a global scale. PNAS | June 16, 2015 | vol. 112 | no. 24 | 7611-7616. www. pnas.org./cgi/doi/10.1073/pnas.1423674112

Dälken, Fabian. (2014). Are Porter's Five Competitive Forces still Applicable? A Critical Examination concerning the Relevance for Today's Business. 3rd IBA Bachelor Thesis Conference, July 3rd, 2014, Enschede, The Netherlands. Copyright 2014, University of Twente, Faculty of Management and Governance. pp. 1-9.

De Guzman, R. et al. (2017). Selected Organic Agricultural Organizations' Social Networks in the Promotion of Organic Agriculture in Quezon Province, Philippines. Asia Pacific Journal of Multidisciplinary Research, Vol. 5, No. 2, pp. 64-76. May 2017. PISSN 2350-7756 E-ISSN 2350-8442 www.apjmr.com

FAS/USDA. (2000). Social and institutional opportunities and constraints of organic agriculture in the Philippines. http://www.tropentag.de/2005/abstracts/full/288.pdf.

Geisen, J. (1999). The Sustainable Vegetable Production Project in Guimaras - empowering local farmers to increase farm income through environmental-friendly vegetable production. Der Tropenlandwirt, eeltrige ur trop/achen landwlrtschalt und Veterlnirmed /n, 100. Jahrgang, April 99, S. 99. 111.

Halberg, Niels. (2012). Assessment of the environmental sustainability of organic farming: Definitions, indicators and the major challenges. Canadian Journal of Plant Science. (2012) 92: 981996 doi: 10.4141/CJPS2012-035. pp.981-996

Herath, C.S. and R. Wijekoon. (2013). Study on attitudes and perceptions of organic and non-organic coconut growers towards organic coconut farming. ConclusionsVolumen 31, No 2. Páginas 5-14 IDESIA (Chile) Mayo-Agosto, 2013

Huang, Ming-the. (2010). Organic Promotion in Response to Consumer DEMAND and Import Substitution: Strategies and Experiences of the Republic of China. From 
Organic Agriculture and Agribusiness: Innovation and Fundamentals APO 2010, ISBN: 92-833-7090-2. Pp. 38-45

IFOAM. (2008). Africa Organic, IFOAM newsletter, 1 (7): [Online] http//www.ifoam.org/newsletter/newsletter-africa/Africaorganic-news-vol.1no.7.html. [Accessed 24 October, 2012].

IFOAM \& FiBL. (2015). The World of Organic Agriculture. Statistics and Emerging Trends 2015. International Federation of Organic Agriculture Movements (IFOAM), Bonn \& Research Institute of Organic Agriculture FiBL, Frick, pp. 50-66; 163-166.

Khaledi, M. (2007). Assessing the Barriers to Conversion to Organic Farming: An Institutional Analysis. Submitted to: Advancing Canadian Agriculture and Agri-Food Saskatchewan (ACAAFS). Department of Agricultural Economics University of Saskatchewan.

Kilcher, L. (2007). How organic agriculture contributes to sustainable development. Journal of Agriculture and Rural Development in the Tropics and Subtropics 89(2007):31-49 ... Archived at http://orgprints.org/10680/.

Landicho, L. D., R.F. Paelmo, R.D. Cabahug, R.G. Visco, M.G. Abadillos. (2014). Prospects and Challenges in Promoting Organic Agriculture in the Upland Communities in the Philippines: Implications to Food Security and Nutrition. 2014 International Conference on Food Security and Nutrition IPCBEE vol.67 (2014) (C) (2014) IACSIT Press, Singapore DOI: 10.7763/IPCBEE. 2014. V67. 12

Lassen, J. (2015). Technologies in organic farming: Consumers' values and acceptance. University of Copenhagen. Paper submitted to the EurSafe2015 Conference: Know your food! - Food Ethics and Innovation. Cluj-Napoca, Romania, May 27-30, 2015. Archived at http://orgprints.org/28538.pp.1-6

Layese, G.F. (2008). Enabling Regulatory Mechanisms for Organic Agriculture in the Philippines. Background Paper presented during the Organic ASIA Conference Sarawak Cultural Village, Kuching, Sarawak, Malaysia 28-31 October 2008.

Maghirang, R.G., R. De La Cruz, R.L. Villareal. (2011). How Sustainable is Organic Agriculture in the Philippines? Trans. Nat. Acad. Sci. \& Tech. (Philippines) Vol. 33 (No. 2) ISSN 0115-8848. pp. 289-321.

Medina, F. and A. Iglesias. (2008). Economic Feasibility of Organic Farms and Risk Management Strategies. 12th Congress of the European Association of Agricultural Economists - EAAE 2008. Pp. 1-11.

Nelson, GL. et.al. (2015). Documentation and Assessment of Socio-cultural Aspects of Organic Agriculture. [Terminal Report]. Department of Agriculture Bureau of Agricultural Research (DA-BAR).

Nikolić, Svetlana Roljević, Predrag Vuković, and Biljana Grujić. (2017).

Measures to Support the Development of Organic Farming in the EU and Serbia. Economics of Agriculture. UDC: 338.246.027:631.147(497.11) (4-672 EU). EP 2017 (64) 1 (323-337) 
Njeru, Moses Kathuri. 2015. Challenges and Benefits of Organic Farming among Farmers in Nembure Division, Embu County-Kenya. International Journal of Humanities and Social Science. Vol. 5, No. 12. ISSN 2220-8488 (Print), 2221-0989 (Online) @Center for Promoting Ideas, USA www.ijhssnet.com

Ohlan, Ramphul. Economic Viability of Organic Farming in Haryana. (2016). A Final Report of Indian Council of Social Science Research Awarded Research Project [NO. 2152/2010-RP]. Research Gate. Pp. 1-79

Olabisi, L.S., R.Q. Wang, A. Ligmann-Zielinska. (2015). Why Don't Farmers Go Organic? Using A Stakeholder-informed Exploratory Agent-Based Model to Represent the Dynamics of Farming Practices in the Philippines. Land 2015, 4,979-1002: doi: 10.3390/land4040979. ISSN 2073-445X. www.mdpi.com/journal/land.

Oluoch-Kosura, Willis. (2010). Institutional innovations for smallholder farmers' competitiveness in Africa. AfJARE Vol 5 No 1 September 2010. Pp. 227-242

Pantoja, Blanquita \& Badayos, Gerdino \& Rola, Agnes. (2016). Constraints to Adoption of

Organic Rice Production in Selected Areas in the Philippines. 10.13140/RG.2.2.31525.50401.

Partap, T. (2010). Emerging Organic Farming Sector in Asia: A Synthesis of Challenges and Opportunities. Asian Productivity Organization. From Organic Agriculture and Agribusiness: Innovation and Fundamentals CAPO 2010, ISBN: 92-833-7090-2. Pp. 8-21

Piadozo, M.E.S., F.A. Lantican, I.M. Panuayon, A.R. Quicoy, A.M. Suyal, P.K.B. Maghirang. (2014). Rice Farmers' Concept and Awareness of Organic agriculture implications for sustainability of Philippine organic agriculture program. J.ISSAAS. Vol.20 No.2; 142-156 (2014).

Pokhrel, Deepak Mani and Kishor Prasad Pant. (2009). Perspectives of Organic Agriculture and Policy Concerns in Nepal. The Journal of Agriculture and Environment. Vol.10. pp. 89-99

Rosenow-Williams, K. (2014). Organizing Muslims and Integrating Islam: Applying organizational sociology to the study of Islamic Organizations. Journal of Ethnic and Migration Studies, 40(5): 759777.

Rola, Agnes C., Blanquita R. Pantoja, Agnes R. Chupungco, Miriam R. Nguyen, and Jaine C. Reyes. (2016). Policy Support to Organic Agriculture in the Philippines. DA-BAR, Diliman, Quezon City, and UPLBFI, College, Laguna, Philippines, 215pp.

Shimoguchi, Nina and Loida Mojica. (2016). Adaptation Strategies to Changing

Environment by an Organic Farm in Laguna, Philippines. IJERD - International Journal of Environmental and Rural Development (2016) 7-2. Pp. 93-98

Salazar, R.C. (2005). Social and institutional opportunities and constraints of organic agriculture in the Philippines. Conference on International Agricultural Research for Development. Tropentag 2005 Stuttgart-Hohenheim. 
Salazar, R.C. (2014). Going Organic in the Philippines: Social and Institutional Features. Agroecology and Sustainable Food Systems. Volume 38, Issue 2. https://www.tandfonline.com/toc/wjsa21/current.

Sarmiento, G. R. (2007). Country Paper - Philippines: Regional Conference on Organic Agriculture in Asia, Bangkok, Thailand. Department of Trade and Industry.

Tadeo, J. S.L. R. M. Baladad, I. Yanny. (2012). Organic Farming at the Center Stage: A Primer on Sustainable Rice Based Farming Systems in the Philippines with additional content from on the Highlights of the 2012 La Via Campesina Southeast Asia Agroecology Exchange.

Tim, S., B. Ngo, L. Siriwattananon, and M. Mihara. (2011). Local Acceptability on Organic Farming in Kampong Cham Province, Cambodia. International Journal of Environment and Rural Development (2011) 2-2. Pp. 89-94.

Torres, J., Valera, D. L., Belmonte, L. J., Sanchez, C. H. (2016). Economic and social sustainability through Organic Agriculture: Study of the restructuring of the Citrus sector in the in the "Bajo Andarax" District (Spain). University of Almeria.

Vogl, Christian R, Lukas Kilcher and Hanspeter Schmidt. (2005). Are Standards and Regulations of Organic Farming Moving Away from Small Farmers' Knowledge? Journal of Sustainable Agriculture, Vol. 26(1) 2005.pp.5-26

Willer, H., L. Kilcher. (2011). The World of Organic Agriculture. Statistics and Emerging Trends 2011. FiBL-IFOAM Report. IFOAM, Bonn and FiBL, Frick.

Yasseen, M. eta al. (2015). Role of Capacity Building and Training for Sustainable Livelihood of Farming Community in Pakistan. European Academic Research - Vol. III, Issue 3 / June 2015. Pp. 3085-3096 